\title{
Numeryczne modelowanie zjawiska dyspersji fizycznej - model rzeczywistej struktury
}

\begin{abstract}
Artykuł dotyczy praktycznego rozwiązania problemu związanego z modelowaniem zjawiska dyspersji fizycznej. Jest to kontynuacja poprzednich publikacji autorów, w których obliczenia zostały wykonane na bardzo uproszczonych modelach symulacyjnych. W ramach pracy dostosowano proponowane wcześniej modyfikacje symulatora BOAST do modeli rzeczywistych struktur posiadających złożoną geometrię oraz niejednorodne rozkłady parametrów złożowych. Zmiany te dotyczyły implementacji hybrydowej metody minimalizacji dyspersji numerycznej oraz rozszerzenia standardowych równań nasyceń o dodatkowy człon dyspersji fizycznej. Praca zawiera krótki opis proponowanej metody sterowania wielkością strefy mieszania się gazów wraz z wynikami jej zastosowania. Ponieważ poprawne modelowanie zjawiska dyspersji fizycznej ma szczególne znaczenie przy symulowaniu wytwarzania bufora PMG oraz późniejszej jego pracy, do przetestowania proponowanej metody użyto modelu krajowego złoża gazu ziemnego, które dzięki specyficznej geometrii oraz dobrym własnościom kolektorskim jest naturalnym kandydatem do konwersji na podziemny magazyn gazu. W ramach pracy skonstruowano kilka modeli geometrycznych wybranej struktury, różniących się od siebie rozdzielczością siatki bloków, na których wykonano szereg symulacji. Wszystkie symulacje dotyczyły procesu wytwarzania poduszki buforowej PMG, podczas którego zachodzi zjawisko mieszania się gazu zatłaczanego z gazem rodzimym znajdującym się w strukturze. Przedstawione w pracy, w postaci rysunków i wykresów, wyniki wykonanych symulacji wykazały efektywność stosowanej metody ograniczenia dyspersji numerycznej (zarówno dla obliczeń mobilności z ważeniem wielopunktowym w kierunku napływu, jak i podwójnej siatki dyskretyzacji) oraz efekty zastosowania różnych wielkości parametrów dyspersji fizycznej.
\end{abstract}

Słowa kluczowe: dyspersja numeryczna, dyspersja fizyczna, mieszanie się gazów, symulator złożowy.

\section{Numerical modeling of physical dispersion in porous rock - model of real structure}

The paper addresses the problem of physical dispersion modeling using a standard reservoir simulator. The paper builds upon the previous works of the authors, where simplified models were used to cope with the problem. Simulator modifications presented there are now applied to a model of real geological structures with complex geometry and inhomogenous distributions of basic reservoir parameters. The modifications include a hybrid method of numerical dispersion reduction and the extension of standard flow equations with physical dispersion terms. The method is briefly described and results of its application are discussed. The proposed approach, is tested on a realistic model of a process to converge a selected domestic gas reservoir with favorable structure and preferred storage parameters, into a practical UGS facility. In particular the first phase of this conversion, i.e. building the gas cushion is modeled where gas-gas mixing phenomena governed by dispersion effects is of significant importance. Several models with different mesh sizes of the structure were constructed and used to simulate the process. The simulation results present the effects of the mixing process between injected and original gases, taking place in realistic porous media and under typical operation conditions. They confirm the practical value of the presented method to successfully reduce unwanted numerical dispersion and efficiently introduce controllable physical dispersion.

Key words: numerical dispersion, physical dispersion, gas mixing, reservoir simulator.

\section{Wstęp}

Podczas zatłaczania gazów do złóż węglowodorowych napotyka się na zjawisko dyspersji fizycznej zachodzące pod- czas mieszania się zatłaczanego gazu z gazem rodzimym występującym w strukturze. Zjawisko to jest bardzo istotne 
w praktykach podziemnego magazynowania gazu [9] (zwłaszcza podczas wytwarzania niewęglowodorowej poduszki buforowej lub zatłaczania wysokometanowego gazu ziemnego do struktur zawierających mocno zanieczyszczony gaz rodzimy) oraz w sytuacjach próby zwiększania energii złoża ropno-gazowego poprzez zatłaczanie gazu do jego czapy gazowej. Niestety w konwencjonalnych symulatorach złożowych (np. Eclipse firmy Schlumberger lub Imex firmy CMG) zjawisko to nie znalazło odpowiedniego rozwiązania. Niniejsza praca objęła modyfikację ogólnodostępnego symulatora złożowego BOAST [3], aby umożliwiał on poprawne modelowanie zjawiska dyspersji fizycznej. Modyfi- kacje dotyczyły implementacji hybrydowej metody minimalizacji dyspersji numerycznej (mobilność z ważeniem wielopunktowym w kierunku napływu + podwójna siatka dyskretyzacji) oraz rozszerzenia standardowych równań nasyceń o dodatkowy człon dyspersji fizycznej o zadanych parametrach. Artykuł ten jest rozszerzeniem poprzednich publikacji autorów, w których zaprezentowano rozwiązania na uproszczonych modelach syntetycznych $[5,6]$. Celem niniejszej pracy było dostosowanie proponowanych modyfikacji symulatora do modeli rzeczywistych struktur posiadających złożoną geometrię oraz niejednorodne rozkłady parametrów złożowych.

\section{Metoda sterowania dyspersją fizyczną}

Zaproponowana w poprzednich pracach autorów metoda sterowania dyspersją fizyczną dzieli się na dwa etapy:

- minimalizację dyspersji numerycznej (rozmycia wyników symulacji wynikających ze stosowanej metody obliczeniowej - dyskretyzacja pochodnych poprzez różnice skończone + upstream weighting zapewniający stabilność rozwiązań numerycznych),

- rozszerzenie równań o człon dyspersji fizycznej (dodanie do symulatora parametrów umożliwiających sterownie dyspersją fizyczną poprzez zadanie stałej wartości dyspersji bądź jej liniowej zależności od prędkości przepływu). Minimalizacja dyspersji numerycznej odbywa się poprzez efektywne połączenie dwóch metod: obliczania mobilności płynów z wykorzystaniem wielopunktowego ważenia w kierunku napływu $[10,11]$ oraz podwójnej siatki dyskretyzacji $[1,7]$. Pierwsza z nich częściowo była już wcześniej zaimplementowana do symulatora BOAST, a dokładniej chodzi o obliczanie mobilności płynów poprzez dwupunktowe ważenie w kierunku napływu. Dla celów skuteczniejszego ograniczenia dyspersji numerycznej w omawianej hybrydowej metodzie rozszerzono obliczanie mobilności płynów o ważenie trzypunktowe.
Dodanie do symulatora parametrów sterujących dyspersją fizyczną $[2,4]$ polega na uwzględnieniu ich w równaniu na przepływy gazu z/do bloków sąsiednich do/z bloku o współrzędnych $i, j, k$ :

$$
\begin{aligned}
\bar{Q}_{g}= & \overline{K A_{c l}} \frac{k_{r g, x}}{\mu_{g} B_{g}} \frac{p_{i-1}-p_{i}}{\frac{\Delta x_{i-1}+\Delta x_{i}}{2}}+\overline{D_{p h y s, x} A_{c l}} \frac{S_{i-1}-S_{i}}{B_{g} \frac{\Delta x_{i-1}+\Delta x_{i}}{2}}+ \\
& +\overline{K A_{c J}} \frac{k_{r g, y}}{\mu_{g} B_{g}} \frac{p_{j-1}-p_{j}}{\frac{\Delta y_{j-1}+\Delta y_{j}}{2}}+\overline{D_{p h y s, y} A_{c J}} \frac{S_{j-1}-S_{j}}{B_{g} \frac{\Delta y_{j-1}+\Delta y_{j}}{2}}+ \\
& +\overline{K A_{c z}} \frac{k_{r g, z}}{\mu_{g} B_{g}} \frac{p_{k-1}-p_{k}}{\frac{\Delta z_{k-1}+\Delta z_{k}}{2}}+\overline{D_{p h y s, z} A_{c z}} \frac{S_{k-1}-S_{k}}{B_{g} \frac{\Delta z_{k-1}+\Delta z_{k}}{2}}(1)
\end{aligned}
$$

gdzie: $\bar{K}$ to przepuszczalność bezwzględna, $\overline{A_{c i}}, \overline{A_{c j}}, \overline{A_{c z}}$, pola przekrojów poprzecznych pomiędzy blokami (pomiędzy $x_{i-1}$ i $x_{i}, y_{j-1}$ i $y_{j}, z_{k-1}$ i $\left.z_{k}\right), k_{r g, x}, k_{r g, y}, k_{r g, z}$-przepuszczalności względne gazu wypierającego w różnych kierunkach, $\mu_{g}$, $B_{g}$ - kolejno: lepkość i współczynnik objętościowy gazu wypierającego, $\Delta x_{i}, \Delta y_{j}, \Delta z_{k}$ - rozmiary bloków w różnych kierunkach, $p_{i, j, k}$ - ciśnienia w blokach, a $S_{i, j, k}$ - nasycenia gazem wypierającym.

\section{Model rzeczywistej struktury - złoże gazu ziemnego}

Ponieważ poprawne modelowanie zjawiska dyspersji fizycznej ma szczególne znaczenie przy symulowaniu wytwarzania bufora PMG oraz późniejszej jego pracy, do przetestowania proponowanej metody wybrano wyeksploatowane krajowe złoże gazu ziemnego, które dzięki specyficznej geometrii oraz dobrym własnościom kolektorskim jest naturalnym kandydatem do konwersji na podziemny magazyn gazu.

Model symulacyjny wybranego złoża w symulatorze BOAST wykonano na podstawie modelu zbudowanego w symulatorze ECLIPSE (firmy Schlumberger) w ramach innej pracy [4].
Ze zbudowanego wcześniej modelu przeniesiono przede wszystkim własności płynów złożowych oraz ich właściwości transportowe. Aby nie komplikować przebiegu analizowanego zjawiska mieszania się gazów, w modelu tym założono takie same własności gazu zatłaczanego i rodzimego (identyczną gęstość, lepkość oraz współczynnik objętościowy). Ponieważ wykonany wcześniej model symulacyjny został skalibrowany w oparciu o dane eksploatacyjne, wykorzystano z niego rozkład ciśnienia złożowego, wynikający z wieloletniej historii eksploatacji i założono go jako ciśnie- 
nie początkowe w nowym modelu symulacyjnym. Ponieważ głównym celem pracy było modelowanie zjawiska mieszania się gazów, do wykonywanych symulacji stworzono scenariusz zakładający konwersję wybranego złoża gazu ziemnego na podziemny magazyn gazu. Zakładana konwersja odbywa się poprzez utworzenie poduszki buforowej magazynu przy użyciu trzech odwiertów wybranych spośród istniejących odwiertów eksploatacyjnych (rysunek 1). Odwiertom tym przypisano wydajność zatłaczania gazu buforowego na poziomie $7062933 \mathrm{ft}^{3} / \mathrm{d}$ i monitorowano migrację zatłaczanego gazu przez okres jednego roku.

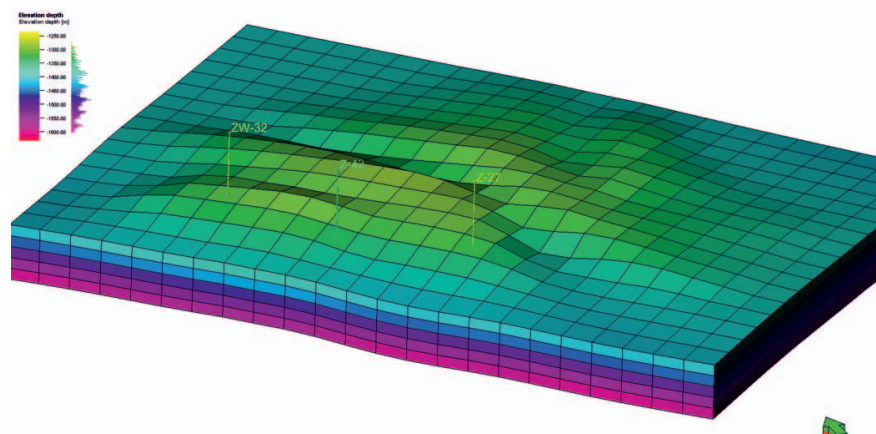

ty

Rys. 1. Trójwymiarowy widok modelu. Rozmieszczenie odwiertów biorących udział w konwersji złoża na PMG

\section{Ograniczenie dyspersji numerycznej}

Wyniki zastosowania proponowanej hybrydowej metody ograniczającej dyspersję numeryczną przedstawiono na rysunkach 3-6. Natomiast rysunek 2 dla porównania przedstawia wynik symulacji bez użycia tej procedury. Za najlepszy wynik ograniczenia dyspersji numerycznej, w przypadku tego modelu, uznano zastosowanie trzypunktowego ważenia dla obliczeń mobilności płynów wraz z dziewięciokrotnym zagęszczeniem siatki dla obliczeń nasyceń. Zastosowanie dziewięciokrotnego zagęszczenia siatki dla obliczeń nasyceń, w porównaniu z modelem bez zagęszczenia, ograniczyło rozmycie frontu mieszania się gazów w kierunkach $X$ i $Y$ o prawie $300 \mathrm{ft}$. Nieco inaczej sytuacja przedstawia się w kierunku pionowym, ponieważ w modelu zastosowano anizotropię przepuszczalności,
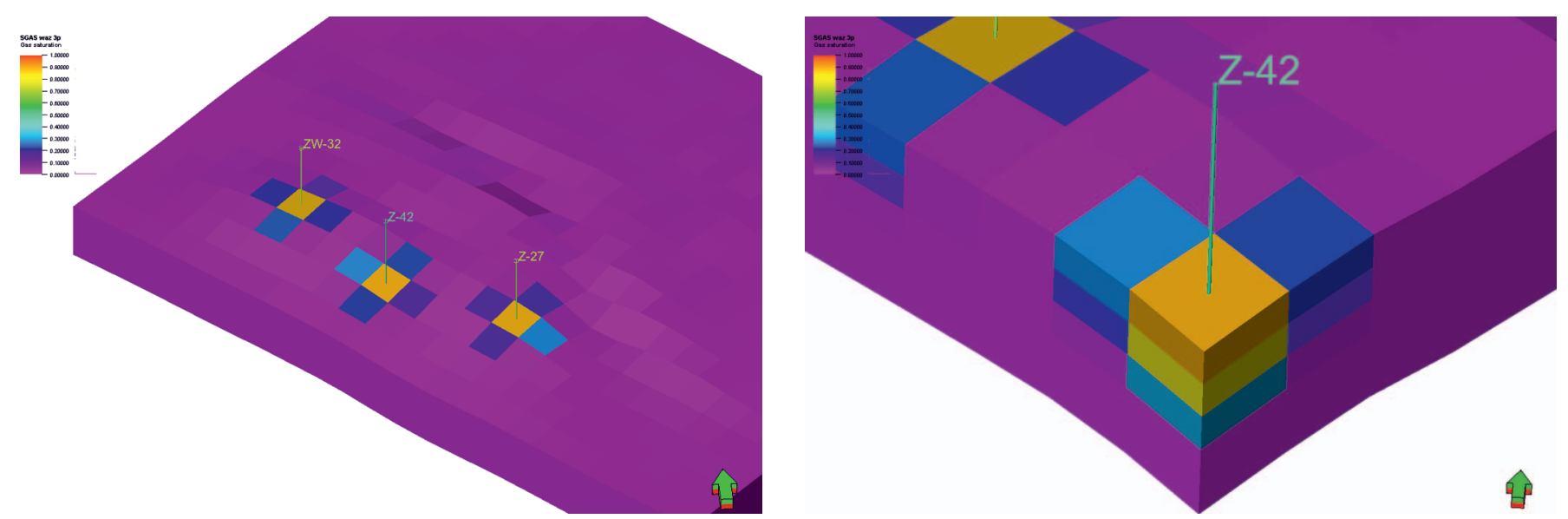

Rys. 2. Widok modelu 3D. Nasycenie gazem zatłaczanym. Wynik symulacji bez ograniczenia dyspersji numerycznej (po lewej widok z góry, po prawej przekrój w pobliżu jednego z odwiertów)
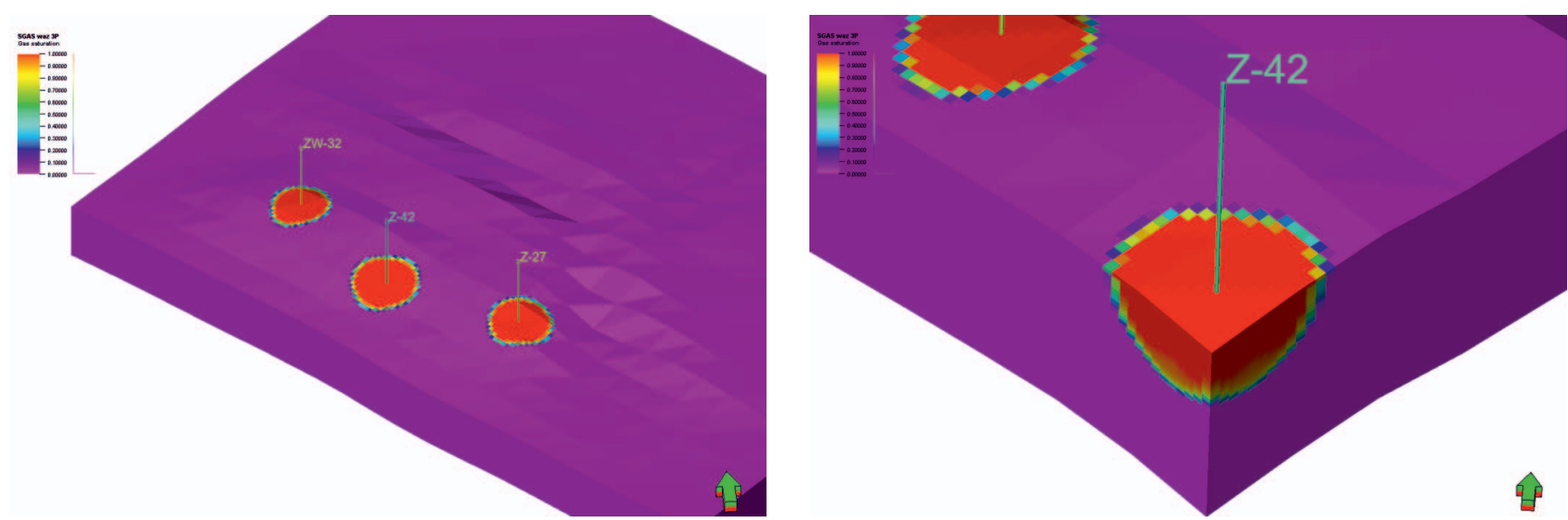

Rys. 3. Widok modelu 3D. Nasycenie gazem zatłaczanym. Wynik symulacji z ograniczeniem dyspersji numerycznej (po lewej widok z góry, po prawej przekrój w pobliżu jednego z odwiertów) 


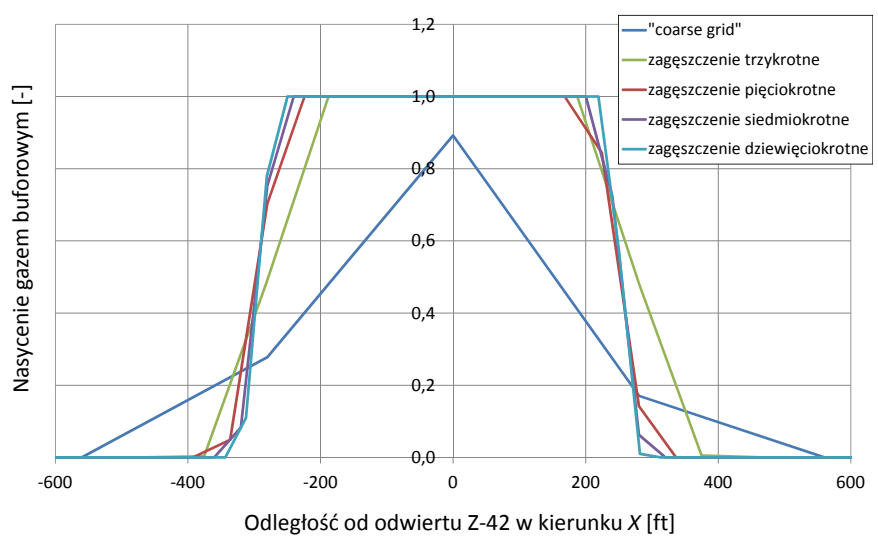

Rys. 4. Nasycenie gazu zatłaczanego w funkcji odległości od odwiertu (kierunek $X$ )

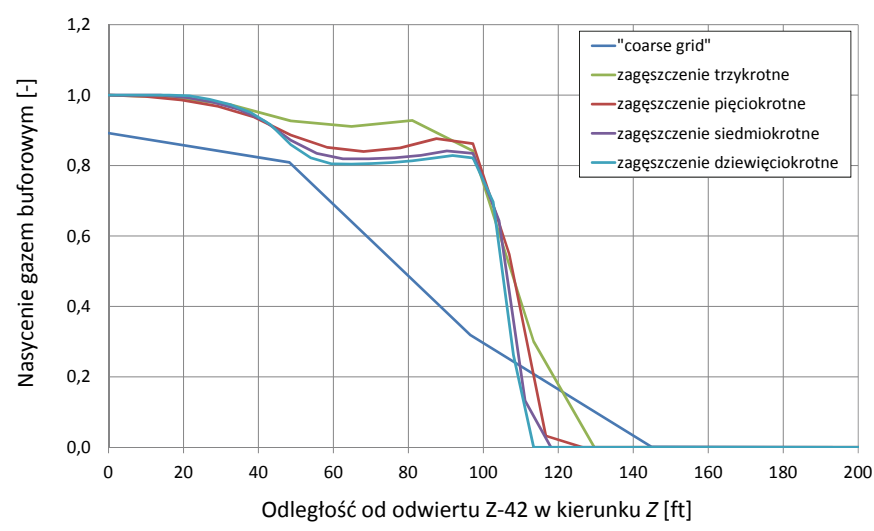

Rys. 6. Nasycenie gazu zatłaczanego w funkcji odległości od odwiertu (kierunek $Z$ )

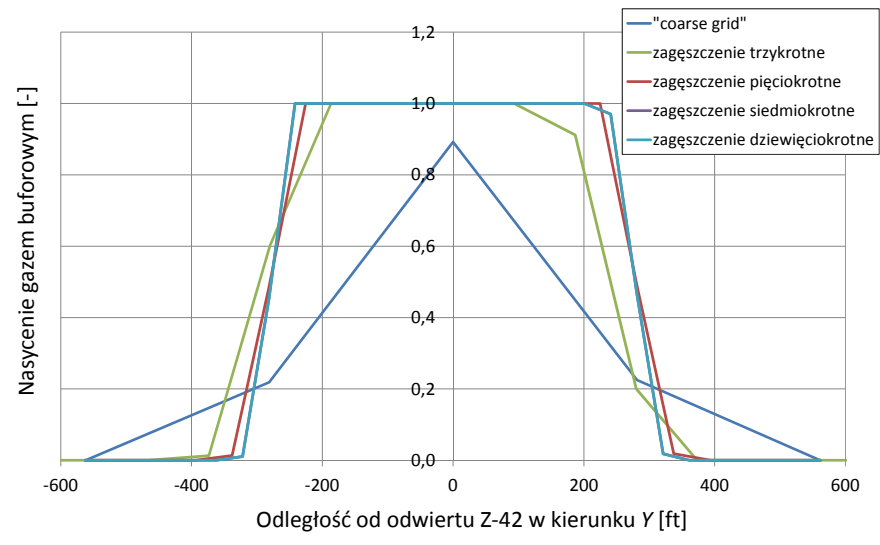

Rys. 5. Nasycenie gazu zatłaczanego w funkcji odległości od odwiertu (kierunek Y)

w wyniku czego przepływ w kierunku $Z$ jest ograniczony w stosunku do przepływu w pozostałych kierunkach. Sytuacja ta wywołuje inne rozmycie frontu mieszania się gazu, co powoduje (również skuteczne) ograniczenie dyspersji numerycznej.

Dalsze zagęszczanie siatki przynosi pożądany efekt w postaci mniejszej dyspersji numerycznej, lecz z każdym kolejnym zagęszczaniem efekt ten jest coraz mniejszy, a wzrastająca liczba bloków, dla których liczone są nasycenia, znacznie wydłuża czas obliczeń.

\section{Sterowanie zjawiskiem mieszania się gazów}

Po optymalnym zminimalizowaniu dyspersji numerycznej wykonano symulacje z kontrolowaną wielkością strefy mieszania się gazu buforowego z gazem rodzimym poprzez zadanie czterech parametrów dyspersji fizycznej, a mianowicie $D_{x}, D_{y}, D_{z}$ oraz $\alpha$, które określają liniowe zależności dyspersji od prędkości przepływu w danym kierunku. Rysunek 7 przedstawia wynik zastosowania takich samych parametrów dyspersji fizycznej we wszystkich kierunkach, w wyniku czego otrzymano symetryczne rozmycie strefy mieszania się gazów większe od rozmycia uzyskanego po zmini-
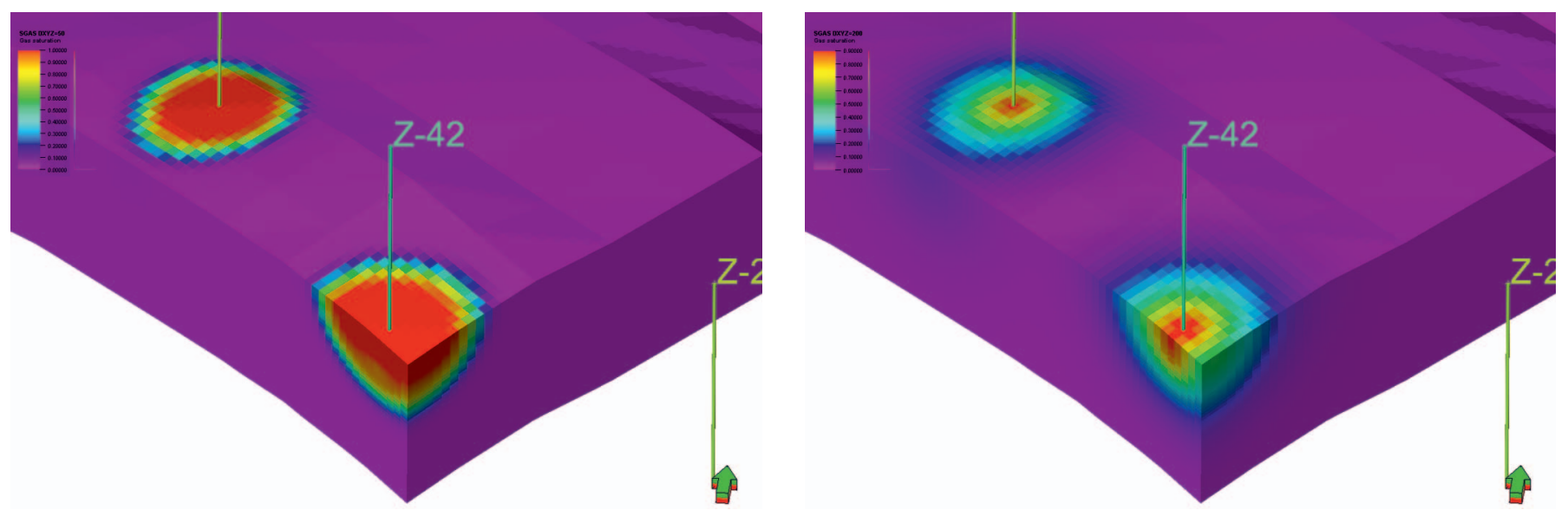

Rys. 7. Widok modelu 3D. Nasycenie gazem zatłaczanym. Po lewej stronie parametry dyspersji fizycznej: $D_{x}, D_{y}, D_{z}=50 \mathrm{ft}^{2} / \mathrm{d}, \alpha=5 \mathrm{ft}$, a po prawej: $D_{x}, D_{y}, D_{z}=200 \mathrm{ft}^{2} / \mathrm{d}, \alpha=5 \mathrm{ft}$ 
malizowaniu dyspersji numerycznej (rysunek 3). Natomiast rysunek 8 przedstawia wyniki zastosowania różnych wielkości dyspersji fizycznej w zależności od kierunku przepływu gazu. Rozmycie frontu mieszania się gazów w tym przypadku nie jest symetryczne i zależy od wielkości zadanego parametru $D$ dla wybranego kierunku.

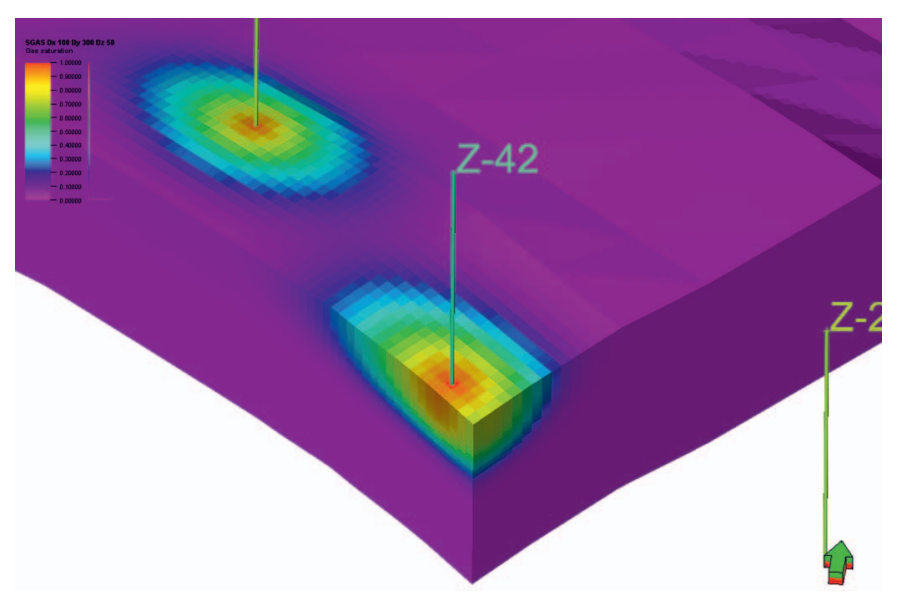

Umożliwione w zmodyfikowanym symulatorze zadawanie różnych parametrów dyspersji, w zależności od kierunku przepływu gazów, w znacznym stopniu ułatwi kalibrację modelu PMG, ponieważ zjawisko dyspersji zachodzące w rzeczywistości zależy od parametrów złożowych, a ich wartości nie rozkładają się symetrycznie we wszystkich kierunkach.

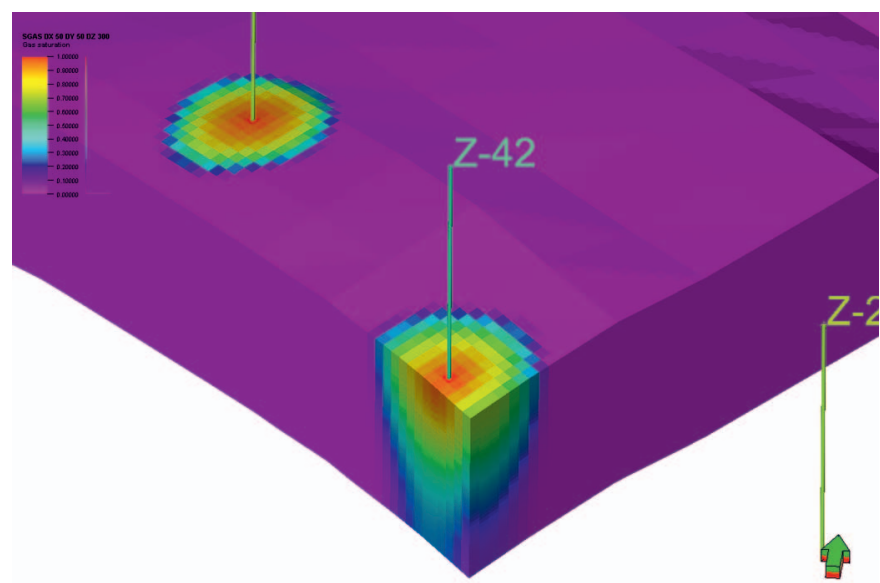

Rys. 8. Widok modelu 3D. Nasycenie gazem zatłaczanym. Po lewej stronie parametry dyspersji fizycznej: $D_{x}=300$, $D_{y}=50, D_{z}=100 \mathrm{ft}^{2} / \mathrm{d}, \alpha=5 \mathrm{ft}$, a po prawej: $D x, D_{y}=50, D_{z}=200 \mathrm{ft}^{2} / \mathrm{d}, \alpha=5 \mathrm{ft}$

\section{Podsumowanie}

W pracy podjęto zagadnienie dotyczące numerycznego modelowania zjawiska dyspersji, występującego podczas konwersji wyeksploatowanego złoża gazu ziemnego na PMG, a dokładniej - podczas wytwarzania jego poduszki buforowej. Ponieważ w standardowych, komercyjnych symulatorach złożowych (typu Eclipse czy CMG) nie udostępniono opcji pozwalających na poprawne modelowanie zjawiska mieszania się gazów, w ramach niniejszej pracy przystosowano (zmodyfikowano niektóre procedury, umożliwiając pracę na modelach rzeczywistych struktur) i wykorzystano (zaimplementowaną do symulatora BOAST) zaproponowaną we wcześniejszych publikacjach metodę polegającą na:

- minimalizacji dyspersji numerycznej poprzez wielopunk- towe ważenie przy obliczeniach mobilności płynów oraz stosowanie podwójnej siatki dyskretyzacji (niezagęszczona siatka do obliczeń ciśnień i zagęszczona do obliczeń nasyceń),

- zadaniu parametrów dyspersji fizycznej (zależnych od kierunku oraz prędkości przepływu) dodanych do symulatora poprzez rozszerzenie o człon dyspersyjny równania przepływu płynów między blokami.

W ramach pracy wykonano również kilka modeli symulacyjnych wybranego krajowego złoża gazu ziemnego, różniących się od siebie rozdzielczością siatki do obliczeń nasyceń, na podstawie których przetestowano zaimplementowaną metodę modelowania zjawiska mieszania się gazów.

\section{Wnioski}

1. Modelowanie zjawiska dyspersji zachodzącego podczas wytwarzania bufora PMG w dotychczasowej praktyce INiG - PIB wymagało manipulowania parametrami modelu niezwiązanymi bezpośrednio z tym zjawiskiem.

2. Modelowanie dyspersji fizycznej wymaga zminimalizowania występującej podczas obliczeń symulacyjnych dyspersji numerycznej, co da się uzyskać poprzez zmianę sposobu obliczeń mobilności płynów oraz zagęszczenie siatki modelu dla obliczeń nasyceń.

3. Przy użyciu zmodyfikowanego $w$ ramach pracy symulatora można poprawnie modelować zjawisko dyspersji fizycznej, uwzględniając przy tym jej złożony charakter.

4. Proponowana metoda sterowania dyspersją fizyczną może być wykorzystywana na modelach rzeczywistych struktur. 
Artykuł powstał na podstawie pracy statutowej pt.: Modelowanie zjawiska dyspersji w złożach naftowych na przykładzie modelu rzeczywistej struktury - praca INiG - PIB na zlecenie MNiSW; nr zlecenia: 25/KZ, nr archiwalny: DK-4100-25/16.

\section{Literatura}

[1] Audigane P., Blunt M.J.: Dual mesh method in upscaling. SPE 79681, 2003.

[2] Bijeljic B., Blunt M.J.: A Physically-Based Description of Dispersion in Porous Media. SPE-102869-MS, 2006.

[3] Fanchi J.R., Harpole K.J., Bujnowski S.W.: BOAST: A threedimensional, three-phase black oil applied simulation tool (Version 1.1) Volume 1: Technical Description and FORTRAN Code. Bartlesville Energy Technology Center 1982.

[4] Gołąbek A., Miłek K., Szott W.: Symulacyjne modelowanie procesu konwersji złoża na PMG i regularnej jego pracy, z udziałem $\mathrm{CO}_{2}$ jako gazu buforowego. Nafta-Gaz 2011, nr 3, s. 153-162.

[5] Gołąbek A., Szott W.: Modyfikacje symulatora złożowego dla potrzeb modelowania zjawisk mieszania się gazów. Nafta-Gaz 2015, nr 3, s. 177-184.

[6] Gołąbek A., Szott W.: Numeryczne modelowanie zjawiska dys- persji fizycznej-modyfikacja petnowymiarowego symulatora złożowego. Nafta-Gaz 2016, nr 7, s. 528-533, 10.18668/ NG.2016.07.05.

[7] Peaceman D.W.: Fundamentals of numerical reservoir simulation. Elsevier Scientific Publishing Company 1977.

[8] Reid R.C., Prausnitz J.M., Polling B.E.: The Properties of Gases and Liquids. New York, USA, McGraw-Hill 1987.

[9] Szott W.: Zastosowanie symulacji komputerowych do modelowania pracy podziemnych magazynów gazu w Polsce. Nafta-Gaz 2010, nr 5, s. 339-344.

[10] Szott W., Gołąbek A.: Symulacyjne modelowanie procesów mieszania się gazów $w$ warunkach złożowych. Nafta-Gaz 2014, nr 3, s. 151-161.

[11] Tood M.R., O’Dell P.M., Hirsaki G.J.: Methods for Increased Accuracy in Numerical Reservoir Simulators. SPE 3516, 1972.

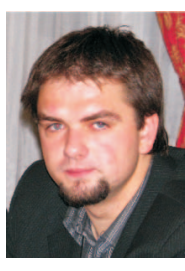

Mgr inż. Andrzej GOŁĄBEK

Asystent w Zakładzie Symulacji Złóż Węglowodorów i Podziemnych Magazynów Gazu.

Instytut Nafty i Gazu - Państwowy Instytut Badawczy ul. Lubicz 25 A

31-503 Kraków

E-mail: andrzej.golabek@inig.pl
Dr Wiesław Szott

Adiunkt; kierownik Zakładu Symulacji Złóż

Węglowodorów i Podziemnych Magazynów Gazu.

Instytut Nafty i Gazu - Państwowy Instytut Badawczy ul. Lubicz $25 \mathrm{~A}$

31-503 Kraków

E-mail: wieslaw.szott@inig.pl

\section{OFERTA}

\section{ZAKŁAD SYMULACJI ZŁÓŻ WĘGLOWODORÓW I PMG}

Zakres działania:

- $\quad$ sporządzanie ilościowych charakterystyk złóż naftowych (konstruowanie statycznych modeli złożowych);

- $\quad$ analizy geostatystyczne dla potrzeb projektowania modeli złóż naftowych, w tym PMG i wielofazowych obliczeń wolumetrycznych;

- $\quad$ konstruowanie dynamicznych symulacyjnych modeli złóż i ich kalibracja;

- wszechstronne badania symulacyjne dla potrzeb:

» weryfikacji zasobów płynów złożowych,

» wtórnych metod zwiększania wydobycia (zatłaczanie gazu lub wody, procesy WAG, procesy wypierania mieszającego, oddziaływanie chemiczne),

» optymalizacji rozwiercania i udostępniania złóż,

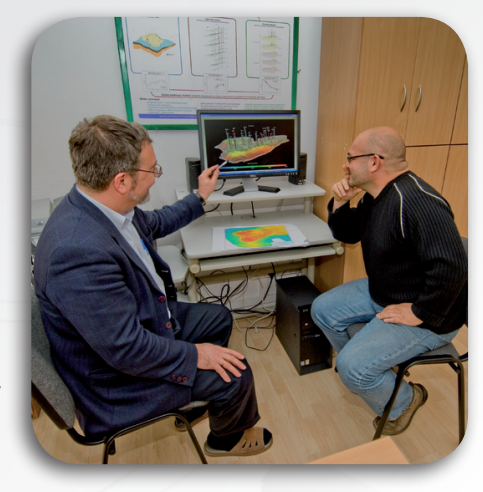

» prognozowania złożowych i hydraulicznych (w tym termalnych) charakterystyk odwiertów (w szczególności poziomych) dla celów optymalnego ich projektowania,

» sekwestracji $\mathrm{CO}_{2}$;

- projektowanie, realizacja i wdrażanie systemów baz danych dla potrzeb górnictwa naftowego.

Kierownik: dr Wiesław Szott

Adres: ul. Armii Krajowej 3, 38-400 Krosno

Telefon: 134368941 w. 5104

Faks: 134367971

E- mail: wieslaw.szott@inig.pl 